\title{
Relationship between plasma cell levels and profile of bronchoalveolar lavage fluid in patients with subacute extrinsic allergic alveolitis
}

\author{
M Drent, SjSc Wagenaar, H van Velzen-Blad, P G H Mulder, H C Hoogsteden, \\ $\mathrm{J} M M$ van den Bosch
}

\begin{abstract}
Background-Plasma cells are usually absent in bronchoalveolar lavage (BAL) fluid. Extrinsic allergic alveolitis is associated with increased numbers of $T$ and B lymphocytes in BAL fluid, as well as the presence of a few plasma cells. The aim of this study was to investigate whether there is a relationship between the presence of plasma cells and other cells, and immunoglobulin levels in BAL fluid of patients with extrinsic allergic alveolitis.
\end{abstract}

Methods-Thirty non-smoking patients with extrinsic allergic alveolitis who had a bronchoalveolar lavage 2-7 days after their last exposure to the causative antigen were selected, retrospectively.

Results-Patients suffering from extrinsic allergic alveolitis with plasma cells in the BAL fluid $(n=18)$ had increased absolute numbers of lymphocytes, eosinophils and mast cells, a decreased percentage of alveolar macrophages and lower CD4/CD8 ratio, as well as higher immunoglobulin levels, when compared with patients with extrinsic allergic alveolitis having no plasma cells in the BAL fluid (n = 12).

Conclusions-The results suggest a relationship between the presence of plasma cells and the other constituents in BAL fluid and a more intense alveolitis. In addition there was a positive relationship between the number of plasma cells in BAL fluid and immunoglobulin levels. These data support the concept of local production of immunoglobulins by plasma cells in the lung following antigen exposure in susceptible individuals.

(Thorax 1993;48:835-839)

The lung is capable of local immunological reactions by cell mediated as well as antibody mediated mechanisms. ${ }^{1}$ In interstitial lung diseases bronchoalveolar lavage (BAL) has become an important method of gaining information about disease processes in the lung. ${ }^{2-4}$ Extrinsic allergic alveolitis is initiated by repeated exposure to specific antigens in susceptible individuals. ${ }^{5-8}$ The immunological mechanisms underlying the pathological changes in the lung appear to be related to the dose of the causative antigens and the duration of exposure. ${ }^{9-11}$ In extrinsic allergic alveolitis initial non-specific inflammation is followed by sensitisation causing a granulomatous inflammatory response modulated by $\mathrm{T}$ cell and macrophage derived cytokines. ${ }^{512}$ This initial phase-that is, immediately after antigen inhalation-is characterised by an increase in the number of neutrophils in BAL fluid. ${ }^{513}$ In the subacute phase, 2-7 days after antigen exposure, the numbers of $\mathrm{CD} 8+$ lymphocytes and natural killer cells are increased. A few plasma cells are occasionally found in the BAL fluid, ${ }^{514}$ but are not generally found in peripheral blood or BAL fluid. If present in BAL fluid, B lymphocytes vary in maturation from small lymphocytes to mature plasma cells, supporting the concept that antigen specific B lymphocytes enter the immunised lung (possibly as lymphoblasts) and mature to plasma cells. ${ }^{16-18}$ Moreover, plasma cells in BAL fluid render allergic or inflammatory processes with an antibody mediated component highly likely. ${ }^{14} 151920$ In addition, immunoglobulin levels in BAL fluid are elevated because of antigenic stimulation in patients with extrinsic allergic alveolitis compared with control subjects. ${ }^{50}$ These high immunoglobulin levels may be caused by an increase in pulmonary vascular permeability, or local production of immunoglobulins, or both. ${ }^{20}$ Plasma cells synthesise and secrete immunoglobulins but no relationship has been shown between plasma cells and immunoglobulin levels in BAL fluid.

In this study we have investigated differences between the profile of the BAL fluid in patients with extrinsic allergic alveolitis, with or without plasma cells, and the relationship of plasma cells with immunoglobulin levels in the lavage fluid.

\section{Methods}

PATIENTS AND CONTROLS

Samples of BAL fluid obtained from patients suffering from extrinsic allergic alveolitis $(n=$ 67; 59 non-smokers and eight smokers) during a 10 year period between 1980 and 1990 were studied. The patients with extrinsic allergic alveolitis presented with generalised constitutional and pulmonary symptomsthat is, cough, dyspnoea, and sometimes fever and chills. Although the symptoms were mostly transient, exacerbations occurred with repeated exposure to the causative antigen. The diagnosis of extrinsic allergic alveolitis was made from clinical information, chest radiology, the presence of serum antibodies 
Table 1. Mean (SE) characteristics of the groups studied: the non-smoking patient population with extrinsic allergic alveolitis (EAA) and non-smoking control subjects

\begin{tabular}{|c|c|c|c|c|c|}
\hline & \multicolumn{4}{|c|}{ Time since last exposure of $E A A$ patients to birds } & \multirow[b]{2}{*}{$\begin{array}{l}\text { Controls } \\
(n=28)\end{array}$} \\
\hline & $\begin{array}{l}<24 \text { hours } \\
(n=12)\end{array}$ & $\begin{array}{l}2-7 \text { days } \\
(n=30)\end{array}$ & $\begin{array}{l}8-30 \text { days } \\
(n=11)\end{array}$ & $\begin{array}{l}1-12 \text { months } \\
(n=6)\end{array}$ & \\
\hline $\begin{array}{l}\text { Avian precipitins } \\
\% \text { PC of total cell } \\
\text { count }\left(\times 10^{4} / \mathrm{ml}\right) \\
P C=0\end{array}$ & $\begin{array}{l}6 A, 3 C, 3 D \\
0.34(0.14)\end{array}$ & $\begin{array}{c}18 \mathrm{~A}, 6 \mathrm{~B}, 2 \mathrm{C}, 4 \mathrm{D} \\
0.58(0 \cdot 15)\end{array}$ & $\begin{array}{l}8 \mathrm{~A}, 3 \mathrm{C} \\
0 \cdot 21(0.09)\end{array}$ & $\begin{array}{l}4 A, 1 B, 1 C \\
0.05(0.03)\end{array}$ & $\begin{array}{l}\text { Not done } \\
0.0(0.0)\end{array}$ \\
\hline $\begin{array}{l}\text { n } \\
\text { Age (range) (y) } \\
\text { Sex } \\
P C>0\end{array}$ & $\begin{array}{l}5 \\
52(23-75) \\
2 F ; 3 M\end{array}$ & $\begin{array}{l}12 \\
54(27-75) \\
5 F ; 7 M\end{array}$ & $\begin{array}{l}5 \\
42(19-65) \\
1 \mathrm{~F} ; 4 \mathrm{M}\end{array}$ & $\begin{array}{l}4 \\
56(28-73) \\
2 F ; 2 M\end{array}$ & $\begin{array}{l}28 \\
39(19-60) \\
12 \mathrm{~F} ; 16 \mathrm{M}\end{array}$ \\
\hline $\begin{array}{l}\text { n } \\
\text { Age (range) (y) }\end{array}$ & $\begin{array}{l}7 \\
54(33-65) \\
2 \mathrm{~F} ; 5 \mathrm{M}\end{array}$ & $\begin{array}{l}18 \\
50(27-70) \\
6 \mathrm{~F} ; 12 \mathrm{M}\end{array}$ & $\begin{array}{l}6 \\
47(22-71) \\
2 F ; 4 M\end{array}$ & $\begin{array}{l}2 \\
52(25-70) \\
\text { OF; } 2 M\end{array}$ & $\begin{array}{l}0 \\
- \\
-\end{array}$ \\
\hline
\end{tabular}

A-pigeon; B-budgerigar; C-canary; D-parrot; PC-plasma cells.

(precipitins, table 1) against the suspected antigens in peripheral blood, pulmonary function tests, and disappearance of symptoms after avoidance of antigen exposure. An open lung biopsy was performed in five patients without sufficient clinical criteria to make a definitive diagnosis. To exclude any influence of smoking on the profile of the BAL fluid only non-smoking patients ( $n=$ 59) were studied, all of whom had been frequently exposed to birds including pigeons, parrots, budgerigars, or canaries (table 1). No patient was on corticosteroid treatment before or at the time of the lavage. The patients were divided into four categories based on the time period between the presumed termination of antigen exposure and the lavage: group 1, <24 hours; group 2, 2-7 days; group 3, 8-30 days; group 4, 1-12 months. The patients with extrinsic allergic alveolitis last exposed 2-7 days before BAL (group 2; $n=30$ ) having the highest number of plasma cells in their lavage fluid were further divided into two subgroups according to the presence or absence of plasma cells in the lavage fluid (table 1) and form the basis of this study.

A control group of 28 non-smoking healthy volunteers with no contact with extrinsic allergic alveolitis inducing antigens was also studied (table 1).

This study was approved by the ethical committee of our hospital.

\section{BRONCHOALVEOLAR LAVAGE}

BAL was performed during fibreoptic bronchoscopy. ${ }^{21}$ Following premedication with atropine and local anaesthesia of the larynx and bronchial tree with tetracaine $0.5 \%$, the right middle lobe was lavaged with four aliquots each of $50 \mathrm{ml}$ sterile saline $(0.9 \%$ $\mathrm{NaCl}$ ) at room temperature. Simultaneous peripheral blood samples were taken.

The recovered BAL fluid was kept on ice in a siliconised specimen trap and separated from its cellular compounds by centrifugation (5 minutes at $350 \mathrm{~g}$ ). Supernatants were directly stored at $-70^{\circ} \mathrm{C}$ after additional centrifugation $(10$ minutes at $1000 \mathrm{~g})$. Cells were washed twice, counted, and suspended in minimal essential medium (MEM; Gibco, Grand Island, New York, USA) supple- mented with $1 \%$ bovine serum albumin (BSA; Organon, Teknika, Boxtel, The Netherlands).

Preparations of cell suspensions were made in a cytocentrifuge (Shandon). Cytospin slides were stained with May-GrünwaldGiemsa (MGG; Merck, Darmstadt, Germany) for cell differentiation and at least 1000 cells were counted. Morphologically, plasma cells were identified in a routine MGG stained slide by light microscopy. Only mature plasma cells recognised by an eccentric nucleus with a large amount of basophilic cytoplasm were included.

If more than $15 \%$ of lymphocytes were present, $T$ cell (sub)populations were determined. Total $T$ cells and subpopulations were recognised by staining with monoclonal antibodies CD2(OKT11), CD3(OKT3), CD4(OKT4), and CD8 (OKT8) from Ortho Pharmaceuticals (Beerse, Belgium). Identification of $T$ cells reacting with monoclonal antibodies was performed by means of a conventional indirect immunofluorescence technique using FITC-labelled goat antimouse (GAM) immunoglobulin (Nordic Immunological Laboratories, Tilburg, The Netherlands and Central Laboratory of the Netherlands Red Cross Blood Transfusion Service (CLB), Amsterdam, The Netherlands). Albumin determinations were performed according to the modified adaptation of the bromocresol purple dye binding method. ${ }^{22}{ }^{23}$ Albumin concentrations in serum and lavage fluid were expressed in $\mathrm{g} / \mathrm{l}$ and $\mathrm{mg} / \mathrm{l}$, respectively.

Immunoglobulin concentrations (IgM, IgG, and IgA) in BAL fluid were measured by an enzyme linked immunosorbent assay (ELISA) method; microtitre plates were coated with a rabbit antihuman isotype antiserum [anti-IgM, (CLB, Amsterdam, The Netherlands), anti-IgG and anti-IgA (Dako, Glostrup, Denmark)]. Bound immunoglobulins from BAL fluid were visualised with a horseradish peroxidase labelled rabbit antihuman immunoglobulin antiserum [with anti-IgA, -IgG, -IgM, -kappa, -lambda reactivity (Dako, Glostrup, Denmark)] and a chromogenic substrate orthophenyl diamine (OPD; Baker Chemicals BV, Deventer, The Netherlands). Immunoglobulin concentra- 
Table 2 Mean (SE) yield, total cell count (TCC), differential cell count (percentage TCC) and absolute numbers of cells $\left(\times 10^{4} / \mathrm{ml}\right)$ in BAL fluid of patients suffering from extrinsic allergic alveolitis $(E A A)$ last exposed 2-7 days before the lavage (group $2 ; n=30)$ with or without plasma cells (PC) in $B A L$ fluid and in control subjects

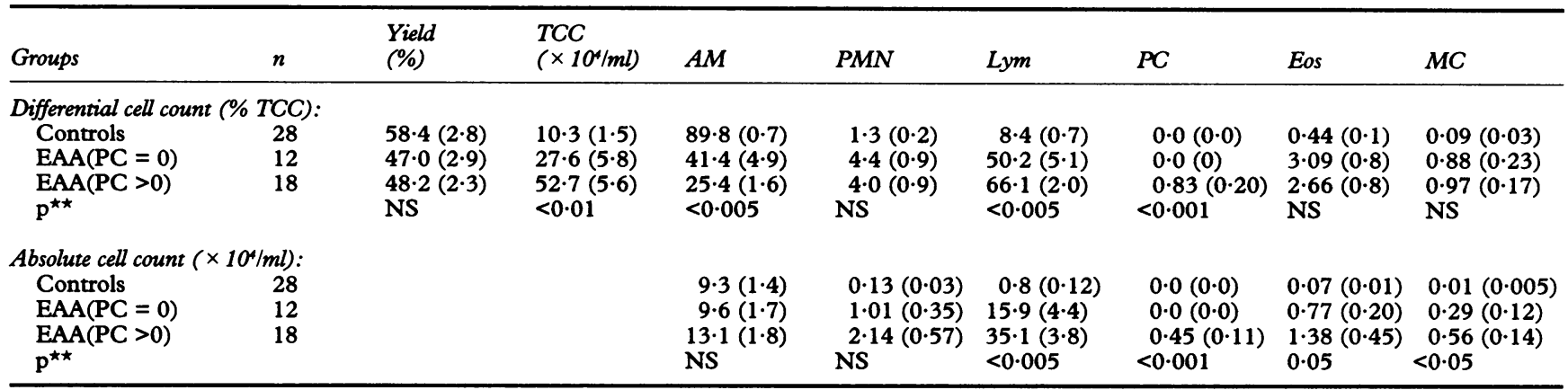

AM-Alveolar macrophages; PMN-polymorphonuclear neutrophils; Lym-lymphocytes: Eos-eosinophils; MC—mast cells; PC—plasma cells;

NS - not significant; ${ }^{\star \star}$ p value: Mann-Whitney test EAA patient group with PC $v$ without PC in the BAL fluid.

tions in BAL fluid were expressed in $\mathrm{mg} / \mathrm{l}$ using as a reference a commercial human standard serum, HOO-03 (CLB, Amsterdam, The Netherlands).

\section{STATISTICAL ANALYSIS}

To investigate whether there were significant differences between the profile of BAL fluid of patients suffering from extrinsic allergic alveolitis, with or without plasma cells, the Mann-Whitney U test was used. Spearman rank correlation coefficients were estimated in order to test against a monotonic relationship between the absolute and relative number of plasma cells in BAL fluid on one hand, and the levels of albumin, IgM, IgG, IgA, and the ratios IgM to albumin, IgG to albumin, and IgA to albumin in BAL fluid on the other. A $p$ value of $<0.05$ was considered to be significant.

\section{Results}

Patients with extrinsic allergic alveolitis who underwent BAL within 2-7 days of antigen exposure (group 2) showed the highest percentage of plasma cells in the BAL fluid (table 1). Moreover, this largest subgroup $(\mathrm{n}=30)$ contained most patients with plasma cells in the lavage fluid $(n=18)$. Furthermore, in this subgroup of patients the lowest value of plasma cells in the lavage fluid was $0.1 \%$ and the highest was $3.9 \%$ in one patient who had a lavage five days after antigen exposure. In none of the groups studied were plasma cells found in peripheral blood. In the patients in group 2 with plasma cells the total cell count $(p<0.01)$, and the absolute and relative number of lymphocytes were increased $(p<0.005)$, and the percentage of alveolar macrophages was decreased
( $p<0.005)$ compared with patients without plasma cells (table 2). The absolute number of eosinophils and mast cells were higher in the patients with plasma cells $(p<0.05)$ than in those without (table 2). Both groups had an increased total cell count $(p<0.001)$, absolute and relative number of lymphocytes ( $p<0.001)$, neutrophils $(p<0.005)$, eosinophils $(p<0.01)$, and mast cells $(p<0.005)$, and a decreased relative number of alveolar macrophages $(p<0.001)$ compared with the control subjects.

The patients with plasma cells had a lower percentage of CD4 $+\mathrm{T}$ cells $(\mathrm{p}<0.05)$ and a significantly lower $\mathrm{CD} 4 / \mathrm{CD} 8$ ratio (median 0.7 ; range $0.4-3.0) \quad(p<0.05)$ than the patients without plasma cells (median 1.9; range $0.5-3.9$ ) (table 3 ). The measured percentages of $T$ cells and $T$ cell subpopulations of both patient groups (with and without plasma cells) showed significant differences when compared with the control group in whom $T$ cell (sub)population determinations were performed $(n=6 ; p<0.01)$, except for the percentage CD4 $+\mathrm{T}$ cells and $\mathrm{CD} 4 / \mathrm{CD} 8$ ratio. The percentage CD4 $+\mathrm{T}$ cells was higher in the patients without plasma cells than in the control subjects $(p<0.05)$ and patients with plasma cells $(p<0.05)$. The $\mathrm{CD} 4 / \mathrm{CD} 8$ ratio was lower in the patient group with plasma cells than in the control group $(p<0.01)$. In BAL fluid of patients with plasma cells the ratio of IgG to albumin was higher $(2.33 v 0.95, \mathrm{p}<0.05)$; the ratios of IgM and IgA to albumin in the lavage fluid tended to be higher than in the patients without plasma cells. The immunoglobulin levels and their ratios to albumin in BAL fluid were higher in both patient groups than in the control group ( $p<0.01$ ) (table 4$)$.

The Spearman rank correlation coefficients

Table 3 Mean (SE) percentages of $T$ lymphocytes and $T$ cell subpopulations in $B A L$ fluid of patients suffering from extrinsic allergic alveolitis (EAA) last exposed 2-7 days before the lavage (group 2) with or without plasma cells (PC) in $B A L$ fluid and control subjects

\begin{tabular}{|c|c|c|c|c|c|c|}
\hline Groups & $n$ & $C D 2$ & $C D 3$ & $C D 4$ & $C D 8$ & $C D 4 / C D 8$ ratio \\
\hline $\begin{array}{l}\text { Controls } \\
\text { EAA }(\mathrm{PC}=0) \\
\text { EAA }(\mathrm{PC}>0) \\
p^{\star}\end{array}$ & $\begin{array}{r}6 \\
9 \\
18\end{array}$ & $\begin{array}{l}67 \cdot 0(9 \cdot 0) \\
86.6(2 \cdot 8) \\
87 \cdot 7(1 \cdot 8) \\
\text { NS }\end{array}$ & $\begin{array}{l}73.0(2.4) \\
87.9(2.8) \\
84.9(2.0) \\
\text { NS }\end{array}$ & $\begin{array}{l}52.4(3.4) \\
57.2(5.9) \\
38.6(4.3) \\
<0.05\end{array}$ & $\begin{array}{l}19 \cdot 0(1 \cdot 4) \\
34 \cdot 3(4 \cdot 1) \\
43 \cdot 4(3 \cdot 8) \\
\text { NS }\end{array}$ & $\begin{array}{r}2.60(0.17) \\
2.04(0.41) \\
1.03(0.19) \\
<0.05\end{array}$ \\
\hline
\end{tabular}

${ }^{\star}$ p value: Mann-Whitney test EAA patient groups with $v$ without $\mathrm{PC}$ in BAL fluid; NS — not significant. 
Table 4 Mean (SE) protein levels in BAL fluid of patients suffering from extrinsic allergic alveolitis (EAA) last exposed 2-7 days before the lavage (group 2) with or without plasma cells (PC) in BAL fluid and control subjects

\begin{tabular}{|c|c|c|c|c|c|c|c|c|}
\hline Groups & $n$ & $\begin{array}{l}I-a l b \\
(m g / l)\end{array}$ & $\begin{array}{l}I g M \\
(m g / l)\end{array}$ & IgM/I-alb & $\begin{array}{l}I g G \\
(m g / l)\end{array}$ & $I g G / I-a l b$ & $\begin{array}{l}I g A \\
(m g / l)\end{array}$ & $\operatorname{Ig} A / I-a l b$ \\
\hline $\begin{array}{l}\text { Controls } \\
\text { EAA (PC = 0) } \\
\text { EAA (PC > 0) } \\
p^{\star}\end{array}$ & $\begin{array}{l}21 \\
12 \\
18\end{array}$ & $\begin{array}{l}71 \cdot 0(8 \cdot 5) \\
137 \cdot 3(24 \cdot 9) \\
181 \cdot 6(25 \cdot 3) \\
\text { NS }\end{array}$ & $\begin{array}{l}0.4(0.1) \\
10.0(3.6) \\
22.8(5.6) \\
0.05\end{array}$ & $\begin{array}{l}0.01(0.002) \\
0.07(0.02) \\
0.14(0.03) \\
\text { NS }\end{array}$ & $\begin{array}{l}11 \cdot 1(2 \cdot 0) \\
115(30 \cdot 3) \\
303(55 \cdot 2) \\
<0.01\end{array}$ & $\begin{array}{r}0.16(0.02) \\
0.95(0.29) \\
2.33(0.53) \\
<0.05\end{array}$ & $\begin{array}{l}3.6(0.7) \\
28.3(6.7) \\
75.2(17.9) \\
<0.05\end{array}$ & $\begin{array}{l}0.05(0.01) \\
0.24(0.05) \\
0.72(0.27) \\
\text { NS }\end{array}$ \\
\hline
\end{tabular}

I-alb-lavage albumin; ${ }^{\star} \mathrm{p}$ value: Mann-Whitney test EAA patient groups with $v$ without PC in the BAL fluid; NS-not significant.

showed a significant monotonic relationship between the absolute and relative number of plasma cells in BAL fluid, and the levels of immunoglobulins and their ratios to albumin (table 5).

The light microscopic evaluation of the five patients who underwent open lung biopsy showed many plasma cells within the alveolar interstitium in all specimens, irrespective of the presence or absence of plasma cells in the lavage fluid.

\section{Discussion}

Extrinsic allergic alveolitis is thought to result from a combination of a type III immune complex and a type IV cell mediated immunological reaction, although the mechanism remains unknown. ${ }^{5}$ Plasma cell derived antibodies have been found in the serum and BAL fluid of patients with extrinsic allergic alveolitis. ${ }^{521}$ Under normal circumstances plasma cells, known as tissue cells, are not found in BAL fluid nor in peripheral blood. However, in the alveolar interstitium of the immunised lung plasma cells frequently occur. ${ }^{18}$ Recently we have shown the presence of plasma cells in the lavage fluid of patients with extrinsic allergic alveolitis and other antibody mediated inflammatory processes of the lung such as drug induced pneumonitis. ${ }^{15}$ This uncommon motile behaviour of plasma cells can probably be explained by damage of the alveolar membranes and non-specific changes in vascular permeability produced by antigen exposure. ${ }^{15} 18$ In addition, the presence of plasma cells in lavage fluid was considered to be a feature of recent antigen exposure, suggesting an active alveolitis. ${ }^{15}$

In the present study the cellular profile of the BAL fluid differed significantly between patients with extrinsic allergic alveolitis last exposed 2-7 days before the lavage (group 2; $\mathrm{n}=30$ ) who had plasma cells in the lavage compared with those who did not. The patients with plasma cells had an even more

Table 5 Spearman rank correlation coefficients (CC) testing a monotonic relationship between the absolute and relative number of plasma cells (PC) in BAL fluid and the levels of immunoglobulins (Igs) and their ratios to albumin

\begin{tabular}{|c|c|c|c|c|c|c|c|}
\hline & $I-a l b$ & $\operatorname{Ig} M$ & IgM/I-alb & $\operatorname{Ig} G$ & $I g G / I-a l b$ & $\operatorname{Ig} A$ & IgA/I-all \\
\hline \multicolumn{8}{|c|}{ Correlation between percentage $P C$ in $B A L$ fluid and Igs } \\
\hline $\mathrm{CC}$ & $0 \cdot 1878$ & 0.4206 & 0.3920 & 0.5796 & 0.4092 & 0.5719 & 0.3329 \\
\hline & NS & $<0.01$ & $<0.05$ & 0.001 & $<0 \cdot 0$ & $<0.001$ & $<0.05$ \\
\hline \multicolumn{8}{|c|}{ Correlation between absolute number PC in BAL fluid and Igs } \\
\hline CC & $0 \cdot 2356$ & 0.4566 & 0.3920 & 0.5687 & 0.3671 & 0.6031 & 0.3235 \\
\hline & NS & $<0.01$ & $<0.05$ & 0.001 & $<0.05$ & $<0.001$ & $<0.05$ \\
\hline
\end{tabular}

I-alb_lavage albumin; CC-Spearman rank correlation coefficient; NS-not significant. active alveolitis with an increased total cell $\stackrel{\circ}{\circ}$ count and increased absolute and relative $\frac{\bar{\sigma}}{\bar{c}}$ numbers of lymphocytes. In addition, the $\underset{\mathbb{D}}{\overparen{D}}$ pattern of $T$ cell subpopulations differed $\frac{2}{2}$ between both groups. The CD4/CD8 ratio in $\infty$ BAL fluid was decreased in the group with $\vec{\circ}$ plasma cells suggesting a more active alveoli- $\overrightarrow{\vec{H}}$ tis in these patients. This finding agrees with $\mathscr{\omega}$ Trentin et $a l^{6}$ who also found a more active alveolitis in patients suffering from extrinsic allergic alveolitis with a decreased CD4/CD8 $\stackrel{\infty}{\infty}$ ratio, although in their study no differentia- $\infty$ tion was made between patients with or with- $\mathcal{G}$ out plasma cells in the lavage fluid. Trentin $ᄋ$ et $a l^{6}$ also showed a shift from the CD8 +predominant cellular profile of BAL fluid of patients with extrinsic allergic alveolitis towards the normal CD4 + predominant pro- $\stackrel{\oplus}{\rightarrow}$ file after removal from exposure to the $\vec{\theta}$ causative antigen, suggesting a change in the alveolitis. In our study we found that the $\mathrm{CD} 4+\mathrm{T}$ cells predominated over CD8 $+\mathrm{T}$ cells in the patient group without plasma cells, whereas the percentages of CD4 4 and CD8 $+\mathrm{T}$ cells were equal in the patients with $\stackrel{\frac{}{\circ}}{\varrho}$ plasma cells in the lavage fluid.

A decrease in $\mathrm{CD} 8+\mathrm{T}$ cell suppressor $\frac{\mathrm{O}}{3}$ activity in extrinsic allergic alveolitis may cause augmented $\mathrm{CD} 4+\mathrm{T}$ cell reactions. ${ }^{24}$ Activated $\mathrm{CD} 4+\mathrm{T}$ cells have been implicated in the cellular and humoral immune responses to antigenic stimulation by the pro- $\times$ duction of cytokines. ${ }^{2526}$ These cytokines $\frac{\sigma}{3}$ recruit alveolar macrophages (gamma interferon), neutrophils (interleukin (IL)-8), $\frac{\mathrm{O}}{3}$ eosinophils (IL-5), mast cells (IL-3), and natural killer cells (IL-2) into immune responses. ${ }^{27} 28$ Activated CD4 $+\mathrm{T}$ cells, espe- $\frac{\vec{O}}{\mathrm{O}}$ cially IL-5 producing CD4 $+\mathrm{T}$ subsets, may be involved in the mediation of eosinophilic $\widetilde{N}$ recruitment into the airways, as suggested by $N$ the preventive effect of depletion of CD4 $+\mathrm{T}$ N cells, but not of CD8 $+\mathrm{T}$ cells, on antigen $\bar{\sigma}$ induced eosinophilic infiltration in mice. ${ }^{25} \mathrm{We}_{0}$ found an increase in the absolute number of $\frac{\sim}{\mathbb{D}}$ eosinophils in the group with plasma cells $\stackrel{?}{+}$ compared with patients without plasma cells, $\frac{T}{T}$ although the absolute numbers of CD $4+\mathrm{T} \stackrel{\mathrm{D}}{\mathrm{D}}$ cells were equal in both groups (data not pre- $\stackrel{\square}{\stackrel{D}{8}}$ sented). This difference in eosinophilia might $\stackrel{\mathbb{Q}}{\complement}$ be caused by different subpopulations of $\bar{\gamma}$ CD4 + T cells causing different IL-5 produc- 8 tion. Like Laviolette et $a l^{29}$ we also found an흥 increased absolute number of mast cells in both groups, particularly in the patients with extrinsic allergic alveolitis with plasma cells. This might be caused by activation of the same $\mathrm{CD} 4+\mathrm{T}$ cell subpopulation, as this subpopulation of T cells produces both IL-3 
(mast cell recruitment), IL-5, and also IL-4 (B cell stimulation). ${ }^{30}$ Additional studies to detect cytokines in both groups of patients with extrinsic allergic alveolitis, with or without plasma cells, are needed to determine the mechanisms leading to local augmentation of antigen sensitive cells in the lung and more or less severe extrinsic allergic alveolitis.

This study is the first report to show increased immunoglobulin levels in BAL fluid in patients suffering from extrinsic allergic alveolitis with plasma cells in the BAL fluid. Synthesis of immunoglobulin has been reported in the lower respiratory tract. ${ }^{29}{ }^{31-33}$ These findings, and those reported in our study, show that immunoglobulin levels and their ratios to albumin in BAL fluid are positively related to the presence of immunoglobulin producing plasma cells in lavage fluid. In this study patients without plasma cells also showed increased levels of immunoglobulins, the levels among patients with plasma cells being higher than in patients without plasma cells. These higher immunoglobulin levels in BAL fluid of patients with plasma cells might be the result of the local production of immunoglobulins by plasma cells in BAL fluid, in addition to enhanced diffusion from the interstitium due to destruction of the basement membrane.

In conclusion, patients suffering from extrinsic allergic alveolitis with plasma cells in the BAL fluid show signs of a more active alveolitis. They have increased absolute and relative numbers of lymphocytes, higher absolute numbers of eosinophils and mast cells, higher immunoglobulin levels and IgG to albumin ratios, as well as a decreased CD4/CD8 ratio in comparison with patients without plasma cells in BAL fluid. In addition, there is a positive relation between the number of plasma cells in BAL fluid and immunoglobulin levels. These data promote the concept of local production of immunoglobulins by plasma cells within the lung following antigen exposure in susceptible individuals. Studies on the relation of time elapsed between antigen exposure and BAL procedure, and the production by plasma cells of IgM, IgG, and IgA, are currently being conducted.

We gratefully acknowledge Dr Michaela Diamant and Dr Henk van Loveren for their advice and critical comments during the preparation of this manuscript, Mona DonckerwolckeBogaert and Els Tuenter for their laboratory work and their help in collecting the data. This study was supported by a grant from Glaxo BV, The Netherlands.

1 Reynolds HY. Lung immunology and its contribution to the immunopathogenesis of certain respiratory diseases. f Allergy Clin Immunol 1986;78:833-47.

2 Klech $\mathrm{H}$, Hutter $\mathrm{C}$. Clinical guidelines and indications for bronchoalveolar lavage (BAL): report of the European Society of Pneumonology Task Group on BAL. Eur Respir f 1990;3:937-74.

3 The BAL Cooperative Group Steering Committee Bronchoalveolar lavage constituents in healthy individuals, idiopathic pulmonary fibrosis, and selected comparison groups. Am Rev Respir Dis 1990;141:169-202.

4 Daniele RP, Elias JA, Epstein PE, Rossman MD. Bronchoalveolar lavage: role in the pathogenesis, diagnosis, and management of interstitial lung disease. $A n n$ Intern Med 1985;102:93-108.

5 Costabel $U$. The alveolitis of hypersensitivity pneumonitis. Eur Respir f 1988;1:5-9.

6 Trentin L, Marcer G, Chilosi M, Ma Chem Sci, Zambello
R, Agostini C, et al. Longitudinal study of alveolitis in hypersensitivity pneumonitis patients: an immunological evaluation. $\mathcal{F}$ Allergy Clin Immunol 1988;82:577-85.

7 Catin A, Bégin R, Drapeau G, Rola-Pleszcznski $M$

Features of bronchoalveolar lavage differentiating hypersensitivity pneumonitis and pulmonary sarcoidosis at time of initial presentation. Clin Invest Med 1984; 7:89-94

8 Salvaggio JE. Immune reactions in allergic alveolitis. Eur Respir $\mathcal{F} 1991 ; 4: 47-59$.

9 Cormier Y. Bélanger J, Laviolette M. Persistent bronchoalveolar lymphocytosis in asymptomatic farmers. $A m$ Rev Respir Dis 1986;133:843-7.

10 Johnson MA, Nemeth A, Condez A, Clarke SW, Poulter LW. Cell-mediated immunity in pigeon breeders' lung: the effect of removal exposure. Eur Respir $\mathcal{F} 1989$ 2:445-50.

11 Haslam PL. Bronchoalveolar lavage in extrinsic allergic alveolitis. Eur Respir $\mathcal{F}$ 1987;154:120-35.

12 Pesci A, Bertorelli G, Dall'Aglio PP, Neri GP, Olivieri D. Evidence in bronchoalveolar lavage for third type immune reactions in hypersensitivity pneumonitis. Eur Respir f 1990;3:359-61.

13 Foumier E, Tonnel AB, Gosset Ph, Wallaert B, Ameisen JC, Voisin C. Early neutrophil alveolitis after antigen inhalation in hypersensitivity pneumonitis. Chest 1985 ; 88:563-7.

14 Costabel U, Bross KJ, Guzman J, Matthys H Plasmazellen und Lymphozytensub-populationen in der bronchoalveolären Lavage bei exogen-allergischer Alveolitis. Prax Klin Pneumol 1985;39:925-6.

15 Drent $M$, Velzen-Blad van H, Diarnant $M$, Wagenaar SjSc, Mulder PGH, Donckerwolcke-Bogaert $\mathrm{M}$, et al. Differential diagnostic value of plasma cells in bronchoalveolar lavage fluid. Chest 1993;103:1720-4.

16 Bice DE, Muggenburg BA. Localized immune memory in the lung. Am Rev Respir Dis 1988;138:165-71.

17 Calvanico NJ, Ambegaonkar SP, Schlueter DP, Fink JN. Immunoglobulin levels in bronchoalveolar lavage fluid from pigeon breeders. $f \mathrm{Lab}$ Clin Med 1980;96:129-40.

18 Bice DE, Gray H, Evans MJ, Muggenburg BA Identification of plasma cells in lung alveoli and interstitial tissues after localized lung immunization. 7 Leucocyte Biol 1987;41:1-7.

19 Barrios R, Fortoul TI, Lupi-Herrera E. Pigeon breeder's disease: immunofluorescence and ultrastructural observations. Lung 1986;164:55-64.

20 Reynolds SP, Edwards JH, Jones KP, Davies BH. Immunoglobulin and antibody levels in bronchoalveolar lavage fluid from symptomatic and asymptomatic pigeon breeders. Clin Exp Immunol 1991;86:278-85

21 Bosch van den JMM, Heye C, Wagenaar SjSc, VelzenBlad van HCW. Bronchoalveolar lavage in extrinsic allergic alveolitis. Respiration 1986;49:45-51.

22 Carter P. Ultramicroestimation of human serum albumin binding of the cationic dye, 5,5'-dibromo-o-cresolsulfonphthalein. Microchem $\mathcal{F}$ 1970;15:531-9.

23 Louderback A, Measley A, Taylor NA. A new dye-binder technic using bromocresol purple for determination of albumin in serum. Clin Chem 1968;14:793-4.

24 Keller RH, Swartz S, Schlueter DP, Bar-Sela S, Fink IN Immunoregulation in hypersensitivity pneumonitis: phenotypic and functional studies of bronchoalveolar lavage lymphocytes. Am Rev Respir Dis 1984;130:766-71.

25 Nakajima H, Iwamoto I, Tomoe S, Matsumura $R$ Tomioka H, Takatsu K, et al CD4 + T lymphocytes and interleukin-5 mediate antigen-induced eosinophil infiltration into the mouse trachea. Am Rev Respir Dis 1992;146:374-7.

26 Rose C, King TE. Controversies in hypersensitivity pneumonitis. Am Rev Respir Dis 1992;145:1-2.

27 Rosen FS, Cooper MD, Wedgwood RJP. The primary immunodeficiencies. $N$ Engl f Med 1984;311:235-42.

28 Kelley J. Cytokines of the lung. Am Rev Respir Dis 1990 141:765-88.

29 Laviolette $M$, Cormier Y, Loiseau A, Soler P, Leblanc P Hance AJ. Bronchoalveolar mast cells in normal farmers and subjects with farmer's lung. Diagnostic, prognostic and physiologic significance. Am Rev Respir Dis 1991; 144:855-60.

30 Emura $M$, Nagai $S$, Takeuchi $M$, Kitaichi $M$, Izumi $T$. In vitro production of $B$ cell growth factor and $B$ cell differentiation factor by peripheral blood mononuclear cells and bronchoalveolar lavage $T$ lymphocytes from patients with idiopathic pulmonary fibrosis. Clin Exp Immunol 1990;83:133-9.

31 Hance AJ, Saltini C, Crystal RG. Does de novo immunoglobulin synthesis occur on the epithelial surface of the human lower respiratory tract? Am Rev Respir Dis 1988;137:17-24

32 Ojanen $T$, Terho EO, Tukiainen H, Mäntyjärvi RA Class-specific antibodies during follow up of patients with farmer's lung. Eur Respir f 1990;3:257-60.

33 Yamaguchi E, Saito S, Okazaki N, Abe S, Kawakami Y. Plasma cells in the bronchoalveolar lavage fluid of patient with eosinophilic pneumonia. Morphologic proof of local production of antibodies. Chest 1988 93:110-3. 